\title{
Does the Timing of Episiotomy Repair Influence the Incidence of Postpartum Hemorrhage? A Randomized Controlled Study
}

\author{
(D) Doğukan Yıldırım¹, (D İçten Olgu Bafali2, (D) Mete Can Ateş3 ${ }^{3}$ (D) Baki Erdem¹, (D) Nadiye Köroğlu1 , (D) Onur Karaaslan4 \\ 1 University of Health Sciences, Istanbul Kanuni Sultan Süleyman Training and Research Hospital, Department of Obstetrics and Gynecology, \\ istanbul, Turkey \\ 2Suluova State Hospital, Obstetrics and Gynecology, Amasya, Turkey \\ 3 University of Health Sciences, Ankara Dr. Zekai Tahir Burak Women Health Training and Research Hospital, Department of Obstetrics and \\ Gynecology, Ankara, Turkey \\ ${ }^{4}$ Hakkari State Hospital, Obstetrics and Gynecology, Hakkari, Turkey
}

\section{Abstract}

Objective: To evaluate the effect of the timing of episiotomy repair on the incidence of postpartum hemorrhage.

Methods: This randomized controlled trial included 307 pregnant women who delivered vaginally and underwent mediolateral episiotomy in a tertiary-care hospital. In Group I, the repair of the episiotomy was started while the placenta was still inside. In Group II, spontaneous delivery of the placenta was waited, and then the repair was initiated. The primary outcome was the incidence of postpartum hemorrhage. Secondary outcomes were the mean blood loss, postpartum $24^{\text {th }}$ hour hemoglobin $(\mathrm{Hb})$ and hematocrit (Hct) levels, mean $\mathrm{Hb}$ and Hct change, and the need for transfusion. Results: The rate of postpartum hemorrhage (>500 mL) did not differ significantly between the two groups (5.2\% in Group I vs. $6.5 \%$ in Group II, $p=0.62$ ). The mean blood loss did not differ significantly between the two groups (206 $\pm 120 \mathrm{~mL}$ in Group I vs. $210 \pm 134 \mathrm{~mL}$ in Group II, $\mathrm{p}=0.76$ ). There was no statistical difference between the two groups regarding postpartum $\mathrm{Hb}$ and Hct levels, mean $\mathrm{Hb}$ and Hct change, and the need for transfusion.

Discussion: Timing of episiotomy repair has no effect on the incidence of postpartum hemorrhage in a tertiary hospital.

Keywords: Episiotomy, postpartum hemorrhage, timing of episiotomy repair

\section{INTRODUCTION}

International Federation of Gynecology and Obstetrics described episiotomy as a surgical incision made in the perineum and vagina by a trained obstetrician to enlarge the vaginal opening (1). For many years, episiotomy has been thought to prevent deep tears that may occur during delivery and provides better healing than natural tears and has been used routinely in nulliparous patients (2). In the Cochrane meta-analysis published in 2000, these ideas were found to be inaccurate and a 'selective' episiotomy was recommended instead of routine episiotomy (3). After this meta-analysis, episiotomy rates have decreased in many countries (4-6). It is recommended that the rate of episiotomy should not exceed $10 \%$ in vaginal deliveries (7). Episiotomy has been identified as a risk factor for postpartum hemorrhage (8-10).

Postpartum hemorrhage complicates $0.5-1 \%$ of vaginal deliveries and remains the most important cause of maternal mortality in the world $(11,12)$. The third stage of labor begins after the birth of the fetus and ends with the separation of the placenta. Postpartum hemorrhage is often seen at this stage. Therefore, proper management of the third stage of labor plays a critical role in preventing postpartum hemorrhage. Uterine atony is the most common cause of postpartum hemorrhage and constitutes $60-80 \%$ of cases (13). Studies to prevent postpartum hemorrhage 
have often focused on the prevention of atony. Episiotomy, if administered, contributes to the loss of blood in the third stage of labor. Considering that postpartum hemorrhage is defined as blood loss of $500 \mathrm{~mL}$ or more in vaginal births, the importance of timing of episiotomy repair can be better understood.

The aim of this randomized controlled study was to investigate the effect of the timing of episiotomy repair on the incidence of postpartum hemorrhage.

\section{METHODS}

This randomized controlled trial was conducted at İstanbul Kanuni Sultan Süleyman Training and Research Hospital between February 2015 and November 2016. The study was approved by the Local Ethics Committee (no. 5896) and was performed in accordance with the 1975 Helsinki Declaration, which was revised in 2000 .

Inclusion criteria were as follows: gestational age between 3642 weeks, singleton pregnancy, cephalic presentation, estimated birth weight between 2500-4500 grams, maternal age between 18-40 years, parity between $0-5$ and episiotomy.

Exclusion criteria were as follows: acute fetal distress, persistent hypertension (>140/90 mm Hg), placenta previa, ablatio placenta, bleeding due to any reason during birth or pregnancy, previous caesarean section, uterine scar, postpartum hemorrhage in previous pregnancies, polyhydramnios, chorioamnionitis, abnormal placentation, coagulation defects, application of vacuum or forceps, hemoglobin $(\mathrm{Hb})<8 \mathrm{gr} / \mathrm{dL}$, anticoagulant or tocolytic use in pregnancy, multiple pregnancy, uterine malformation, deep vaginal or cervical laceration, no need for episiotomy, manual removal of the placenta, vaginal hematoma and postpartum atony.

Power analysis was performed before the study. In a previous study, a $\mathrm{Hb}$ decrease of $1.62 \mathrm{gr} / \mathrm{dL}$ was detected during delivery. Given this value, it was determined that at least 150 patients should be taken in both groups in order to achieve a $20 \%$ decrease in blood loss compared to the control group with an $80 \%$ power and a p value less than 0.05 . Initially, 443 pregnant women were included in the study. Informed consent was obtained from pregnant women who were admitted for labor and agreed to participate in the study. Standard forms were prepared for both groups and half of them were labeled as "placenta inside", and the other half was labeled as "placenta outside". The prepared forms were put in opaque envelopes. When the pregnant woman was taken to the maternity table, one of the envelopes was pulled, and the randomization was achieved.
Mediolateral episiotomy was performed to all pregnant women included in the study. In case of clinical necessity, superficial perineal anesthesia was performed with $4 \mathrm{~mL}$ Jetocaine ampoule $\left(\mathrm{ADEKA}^{\circledR}\right.$, lidocaine $\mathrm{HCl} 40 \mathrm{mg} / 2 \mathrm{~mL}$, epinephrine $0.025 \mathrm{mg} / 2 \mathrm{~mL}$ ) and episiotomy was performed on the right mediolateral region at an angle of 45 degrees at the level of 7-8 o'clock during the crowning of the head of the fetus. After the fetus was born, the pulsation of the umbilical cord was expected to weaken and was then clamped. Sterile disposable collection bags (Brass $\vee$ Shape, Ekin-Turkey) were placed to the delivery table in order to determine the amount of hemorrhage. After amniotic fluid drainage with delivery, the zipper of the bag was opened and left open for one hour. In group I (placenta inside group), the episiotomy repair was started after the fetus was born while the placenta was not separated. If the placenta showed signs of separation while the repair was in progress, the placenta was removed, and the repair was resumed. In group II (placenta outside group), the placenta was expected to separate spontaneously, and then the repair was initiated. During placental separation, excessively bleeding vaginal vessels were clamped. In both groups, controlled cord traction or any other procedure was not performed to separate the placenta. The vagina was sutured with size 1 polyglactin 910 (Ethicon ${ }^{\circledR}$ Vicryl Rapid $^{\mathrm{TM}}$ ) by continuous locking technique. The perineal muscles and subcutaneous tissue were sutured by interrupted suture technique. The skin was sutured with size 0 vicryl (Doğsan ${ }^{\circledR}$ Pegelak $^{\circledR}$ Rapid) by interrupted suture technique. Ten IU of oxytocin was administered intramuscularly after the separation of the placenta in both groups. The third stage of birth was similarly managed in other respects.

$\mathrm{Hb}$ and hematocrit $(\mathrm{Hct})$ levels were recorded from all pregnant women during the hospitalization. If the placenta did not separate spontaneously within 30 minutes, it was performed manually. Uterine tonus was evaluated every 15 min until the patient left the delivery room. If the vaginal bleeding persisted, the cervix and episiotomy line were re-evaluated for tears that could be overlooked. Episiotomy line of the patients with hematoma was opened and sutured again. Uterine massage and extra uterotonics were used in case of atony. $\mathrm{Hb}$ and $\mathrm{Hct}$ levels of all patients were recorded on postpartum day 1. Transfusion was performed to women who had $\mathrm{Hb}$ levels less than $8 \mathrm{~g} / \mathrm{dL}$ and had symptoms of anemia.

\section{Statistical Analysis}

Jamovi v0.8.6.000 program was used for statistical analysis. Shapiro-Wilk analysis was used to evaluate normality of continuous variables. The data with normal distribution were 
analyzed by independent samples t-test and the data with nonnormal distribution were analyzed by Mann-Whitney $U$ test. Chi-square test was used for categorical variables and Fisher's exact test was used for appropriate data. $\mathrm{P}<0.05$ was accepted as statistically significant.

\section{RESULTS}

Initially, 443 pregnant women were included in the study (Figure 1). Following patients were excluded from the study: 26 patients due to urgent cesarean need, 98 patients due to lack of need for episiotomies and 2 patients due to vacuum application. Three hundred and seventeen pregnant women were randomized into two groups, 160 patients in group I and 157 patients in group II. Six patients in group I and four patients in group II were excluded from the study due to deep vaginal tears, hematoma, atony or manual removal of placenta. So, 154 women in group I and 153 women in group II were included in the study and their results were analyzed.

The clinical characteristics of the study cohort are shown in Table 1. There were no statistically significant differences between

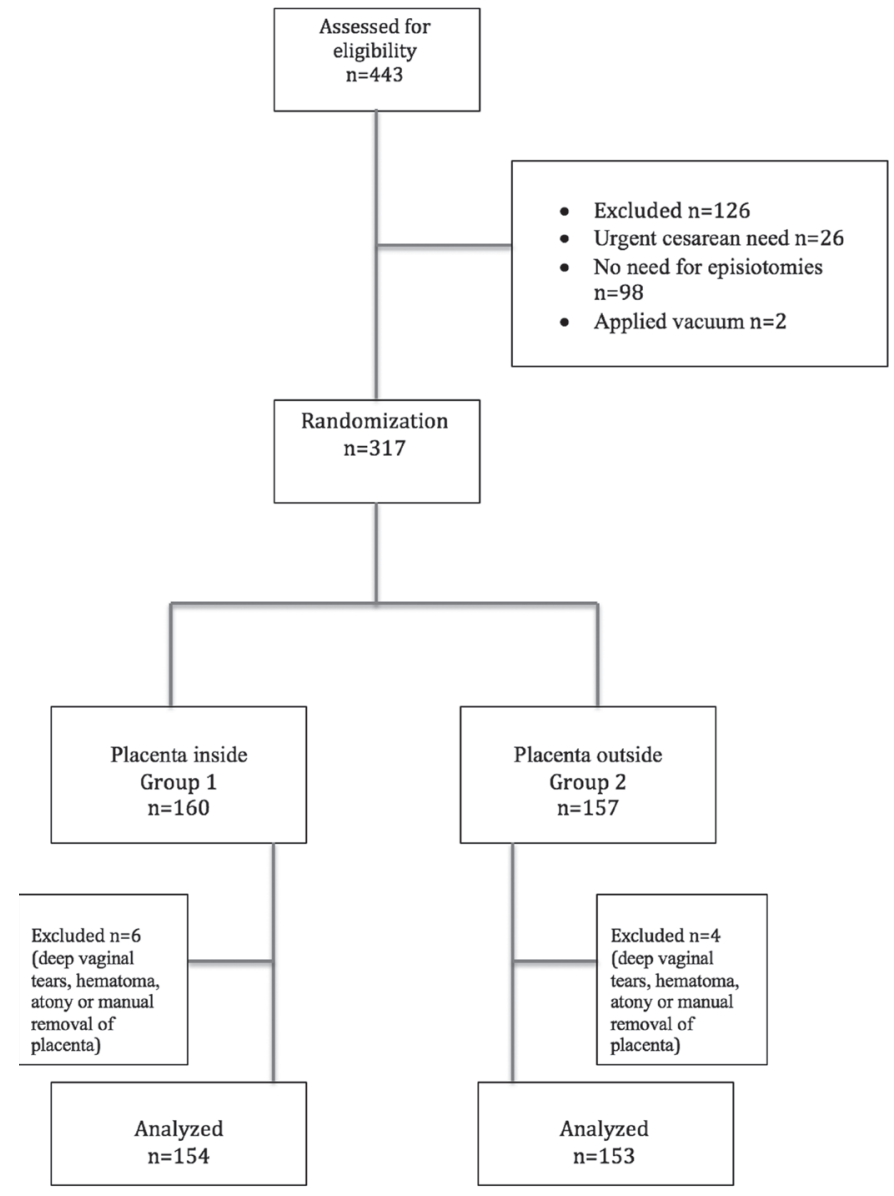

Figure 1. Study flow chart the two groups in terms of age, body mass index, gestational week, birth weight, prepartum $\mathrm{Hb}$, augmentation and parity. Prepartum Hct level was significantly lower in group I $(p=0.04)$.

Table 2 shows the results of the study. No statistically significant difference was found between the two groups in terms of the number of women with blood loss $>500 \mathrm{~mL}[(8 / 154$ (5.2\%) in group I vs. $10 / 153(6.5 \%)$ in group II, $p=0.62)]$. No statistically significant difference was found between the two groups in terms of mean blood loss $(206 \pm 120 \mathrm{~mL}$ in group I vs. $210 \pm 134 \mathrm{~mL}$ in group II, $p=0.76$ ). There was no statistical difference between

\begin{tabular}{|c|c|c|c|}
\hline & $\begin{array}{l}\text { Group I } \\
\text { (Placenta } \\
\text { inside) } \\
\mathrm{n}=154 \\
\end{array}$ & $\begin{array}{l}\text { Group II } \\
\text { (Placenta } \\
\text { outside) } \\
\mathrm{n}=153 \\
\end{array}$ & $p$ \\
\hline Age, years & $24.5(4.5)$ & $24.2(4.3)$ & 0.55 \\
\hline $\mathrm{BMI}, \mathrm{kg} / \mathrm{m}^{2}$ & $26.9(2.3)$ & $27.1(1.9)$ & 0.29 \\
\hline Gestational age, weeks & $38.8(1.2)$ & $38.7(1.3)$ & 0.67 \\
\hline Birth weight, grams & $3205(354)$ & $3260(375)$ & 0.19 \\
\hline Prepartum Hb, g/dL & $11.6(1.4)$ & $11.9(1.5)$ & 0.12 \\
\hline Prepartum Hct, \% & $35.1(3.6)$ & $36.3(3.7)$ & $0.04 *$ \\
\hline Augmentation, n (\%) & $75(49)$ & $72(47)$ & 0.77 \\
\hline \multicolumn{4}{|l|}{ Parity, n (\%) } \\
\hline Nulliparous & $123(79.9)$ & $129(84.3)$ & \multirow[t]{2}{*}{0.31} \\
\hline Multiparous & $31(20.1)$ & 24 (15.7) & \\
\hline
\end{tabular}

\begin{tabular}{|c|c|c|c|}
\hline & $\begin{array}{l}\text { Group I } \\
\text { (Placenta } \\
\text { inside) } \\
\mathrm{n}=154\end{array}$ & $\begin{array}{l}\text { Group II } \\
\text { (Placenta } \\
\text { outside) } \\
\mathrm{n}=153\end{array}$ & $p$ \\
\hline The amount of bleeding, $\mathrm{mL}$ & $206(120)$ & $210(134)$ & 0.76 \\
\hline Blood loss >500 mL, n (\%) & $8(5.2)$ & $10(6.5)$ & 0.62 \\
\hline Postpartum $24^{\text {th }}$ hour $\mathrm{Hb},(\mathrm{g} / \mathrm{dL})$ & $10.3(1.4)$ & $10.4(1.6)$ & 0.12 \\
\hline$\Delta \mathrm{Hb}, \mathrm{g} / \mathrm{dL}$ & $1.31(0.7)$ & $1.47(0.9)$ & 0.13 \\
\hline Postpartum $24^{\text {th }}$ hour Hct, $\%$ & $30.9(3.6)$ & $31.7(3.8)$ & 0.08 \\
\hline$\Delta \mathrm{Hct}, \%$ & $4.21(2)$ & $4.65(2.3)$ & 0.06 \\
\hline Transfusion, n (\%) & $3(2)$ & $3(1.9)$ & 0.99 \\
\hline \multicolumn{4}{|c|}{$\begin{array}{l}\text { All variables were expressed as mean (standard deviation). } \\
\mathrm{Hb} \text { : Hemoglobin, Hct: Hematocrit, } \Delta \mathrm{Hb} \text { : Hemoglobin difference; } \Delta \mathrm{Hct} \text { : Hematocri } \\
\text { difference }\end{array}$} \\
\hline
\end{tabular}


the two groups regarding postpartum $\mathrm{Hb}$ and $\mathrm{Hct}$ levels, mean peripartum $\mathrm{Hb}$ and $\mathrm{Hct}$ change, and the need for transfusion.

\section{DISCUSSION}

Postpartum hemorrhage is defined as blood loss of $500 \mathrm{~mL}$ or more within 24 hours following vaginal delivery. Most of the maternal deaths occur in this critical 24 hours, mainly as a consequence of uterine atony (8). In 2007, the World Health Organization (WHO) recommended the use of active management in the third stage of labor in order to prevent postpartum hemorrhage (14). Active management has three components: administration of uterotonic agent, early cord clamping and controlled traction of the umbilical cord. The use of two of these three components of active management is controversial: early cord clamping leads to low levels of neonatal $\mathrm{Hb}$, and controlled traction of the cord requires experienced practitioners and may cause severe side effects such as inversion. In a multicentre study in 23681 pregnant women, Gülmezoğlu et al. (15) reported that the main component of active management was the use of uterotonic agent and that omission of controlled cord traction did not affect postpartum hemorrhage.

In Cochrane meta-analysis, Westhoff et al. (16) compared the use of different uterotonic agents in the third stage of labor and found that prophylactic oxytocin was superior to the ergot alkaloids in preventing postpartum hemorrhage. WHO published a new guide in 2012 stating that the use of oxytocin (10 IU IV/ IM) in the prevention of postpartum hemorrhage should be the first choice, but that the timing of oxytocin administration is optional (17). In a Cochrane meta-analysis comparing the timing of oxytocin administration, Soltani et al. (18) reported that the application of oxytocin before or after the removal of placenta had no effect on the incidence of postpartum hemorrhage (18). In a recent study, this finding was found to be similar in low-risk pregnancies (19).

Studies on postpartum hemorrhage have rightly focused on the prevention of uterine atony, the most common cause. However, there are other factors affecting the amount of postpartum hemorrhage. Episiotomy is estimated to cause extra blood loss of 300-600 mL (2). Mediolateral episiotomies have more blood loss than midline episiotomies (8). In patients undergoing episiotomy, repair is often performed after the placenta has been removed. In theory, suturing the episiotomy without waiting for the placenta removal may reduce blood loss. There is limited number of studies investigating this issue.

Baksu et al. (20) found that the repair of the mediolateral episiotomy with the placenta inside caused a lower $\mathrm{Hb}$ and $\mathrm{Hct}$ difference than the repair after removal of the placenta. Kelekci et al. (21) found that postpartum $\mathrm{Hb}$ levels were significantly lower in women who underwent episiotomy repair while the placenta was inside, however postpartum Hct levels remained similar between the two groups. Özdeğirmenci et al. (22) found no difference in mean blood loss, mean $\mathrm{Hb}$ and $\mathrm{Hct}$ decrease between the two groups. Dündar et al. (23) found that the mean $\mathrm{Hb}$ and $\mathrm{Hct}$ differences were similar between the two groups.

Our study showed that the primary outcome parameter, the timing of mediolateral episiotomy repair, has no effect on the incidence of postpartum hemorrhage. There was no difference between the two groups in terms of secondary outcomes, including mean blood loss, mean $\mathrm{Hb}$ and $\mathrm{Hct}$ changes. The major limitation of our study was that only the data analyst could be blinded. The practitioner could not be blinded because of the different behaviors required for the interventions being tested. The other limitation was the lack of data on the duration of placental separation and additional analgesic requirement. The strength of the study was that it was a randomized, controlled study and that the blood loss was calculated not only by peripartum $\mathrm{Hb}$ and $\mathrm{Hct}$ changes, but also by collection bags.

\section{CONCLUSION}

Timing of episiotomy repair has no effect on the incidence of postpartum hemorrhage in a tertiary-care hospital. In our country, approximately 1.3 million births occur annually and mediolateral episiotomy is performed frequently. It is reasonable to avoid routine episiotomy to prevent blood loss due to episiotomy. In cases where episiotomy is performed, the timing of repair can be left to the choice of the practitioner. Randomized controlled trials are needed to better clarify the subject.

\section{Ethics}

Ethics Committee Approval: The study was approved by the Local Ethics Committee (no. 5896) and was performed in accordance with the 1975 Helsinki Declaration, which was revised in 2000.

Informed Consent: Informed consent was obtained from pregnant women who were admitted for labor and agreed to participate in the study.

Peer-review: Externally peer-reviewed.

\section{Authorship Contributions}

Surgical and Medical Practices: D.Y., I.O.B., M.C.A., O.K., Concept: D.Y., Design: D.Y., Data Collection or Processing: I.O.B., M.C.A., 
O.K., Analysis or Interpretation: I.O.B., B.E., N.K., Literature Search: D.Y., I.O.B., M.C.A., Writing: D.Y., I.O.B., M.C.A., B.E., N.K., O.K.

Conflict of Interest: No conflict of interest was declared by the authors.

Financial Disclosure: The authors declared that this study received no financial support.

\section{REFERENCES}

1. FIGO 2012, FIGO Safe Motherhood and Newborn Health (SMNH) Committee. Management of the second stage of labor. International Federation of Gynecology and Obstetrics 2012;119:110-6.

2. Myers-Helfgott MG, Helfgott AW. Routine use of episiotomy in modern obstetrics: should it be performed? Obstet Gynecol Clin North Am 1999;26:305-25.

3. Carroli G, Belizan J. Episiotomy for Vaginal Birth. Cochrane Review; in The Cochrane Library, Oxford Update Software. 2000;1.

4. Gurol-Urganci I, Cromwell DA, Edozien LC, Mahmood TA, Adams EJ, Richmond $\mathrm{DH}$, et al. Third- and fourthdegree perineal tears among primiparous women in England between 2000 and 2012: time trends and risk factors. BJOG 2013;120:1516-25.

5. Frankman EA, Wang L, Bunker CH, Lowder JL. Episiotomy in the United States: has anything changed?. American Journal of Obstetrics and Gynecology 2009;200:e1-e7.

6. Räisänen $\mathrm{S}$, Vehviläinen-Julkunen $\mathrm{K}$, Gisler M, Heinonen S. A populationbased register study to determine indications for episiotomy in Finland. Int J Gynaecol Obstet 2011;115:26-30.

7. Baksu B, Davas I, Akyol A, Ozgul J, Ezen F. Effect of timing of episiotomy repair on peripartum blood loss. Gynecol Obstet Invest 2007;65:169-73.

8. Combs CA, Murphy EL, Laros RK Jr. Factors associated with postpartum hemorrhage with vaginal birth. Obstet Gynecol 1991;77:69-76.

9. Wetta LA, Szychowski JM, Seals S, Mancuso MS, Biggio JR, Tita AT. Risk factors for uterine atony/postpartum hemorrhage requiring treatment after vaginal delivery. Am J Obstet Gynecol 2013;209:51 e51-51-e56.

10. Magann EF, Evans S, Hutchinson M, Collins R, Howard BC, Morrison JC. Postpartum hemorrhage after vaginal birth: an analysis of risk factors South Med J 2005;98:419-22.
11. Deneux-Tharaux C, Sentilhes L, Maillard F, Closset E, Vardon D, Leperca J, et al. Effect of routine controlled cord traction as part of the active management of the third stage of labor on postpartum hemorrhage: multicenter randomized controlled trial (TRACOR). BMJ 2013;346:f1541.

12. Khan KS, Wojdyla D, Say L, Gulmezoglu AM, Van Look PF. WHO analysis of causes of maternal death: a systematic review. Lancet 2006;367:1066-74.

13. Oyelese Y, Ananth CV. Postpartum hemorrhage: epidemiology, risk factors, and causes. Clin Obstet Gynecol 2010;53:147-56.

14. World Health Organization: Recommendations for the prevention of postpartum haemorrhage. 2007 Retrieved from http://apps.who.int/ rhl/ effective_practice_and_organizing_care/guideline_pphprevention_ fawoleb/ en/index.html (Accessed January 15 2017)

15. Gülmezoglu AM, Lumbiganon P, Landoulsi S, Widmer M, Abdel-Aleem H, Festin M, et al. Active management of the third stage of labour with and without controlled cord traction: a randomized, controlled, non-inferiority trial. Lancet 2010;379:1721-7.

16. Westhoff G, Cotter AM, Tolosa JE. Prophylactic oxytocin for the third stage of labour to prevent postpartum haemorrhage. Cochrane Database Syst Rev 2013;10:CD001808.

17. World Health Organization: WHO recommendations for the prevention and treatment of postpartum haemorrhage. 2013 Retrieved from http://apps. who. int/iris/bitstream/10665/75411/1/9789241548502_eng.pdf (Accessed March 23, 2017)

18. Soltani H, Poulose TA, Hutchon DR. Placental cord drainage after vaginal delivery as part of the management of the third stage of labor. Cochrane Database Syst Rev 2011;9.

19. Yildirim D, Ozyurek SE. Intramuscular oxytocin administration before vs, after placental delivery for the prevention of postpartum hemorrhage: A randomized controlled prospective trial.Eur J Obstet Gynecol Reprod Biol 2018;224:47-51.

20. Baksu B, Davas I, Akyol A, Ozgul J, Ezen F. Effect of timing of episiotomy repair on peripartum blood loss. Gynecol Obstet Invest 2007;65:169-73.

21. Kelekci S, Savan K, Yaşar L, Sönmez S, Şahin L, Şentürk A. Epizyotomi Tamirinin Plasenta Cıkıșından Önce veya Sonra Yapılmasının Peripartum Kan Kaybına Etkisi. Perinatoloji Dergisi 2002;10:331-5.

22. Ozdegirmenci O, Erkaya S, Yalvac S, Dilbaz B, Altinbas S, Haberal A. Does early repair of episiotomy decrease postpartum blood loss: A randomized clinical trial. J Matern Fetal Neonatal Med 2010;23:308-10.

23. Dündar Ö, Çiftpınar T, Yörük P, Tütüncü L, Müngen E, Yergök YZ. Epizyotomi Onarımı Zamanının Postpartum Kan Belirteçlerine Etkisi. Trakya Univ Tip Fak Derg 2009;26:203-7. 